\title{
Comparison of predation pressure in temperate and subtropical seagrass habitats based on chronographic tethering
}

\author{
Bradley J. Peterson ${ }^{1, *}$, Kip R. Thompson ${ }^{1}$, James H. Cowan $\mathrm{Jr}^{2}{ }^{2}$, Kenneth L. Heck $\mathrm{Jr}^{2}$ \\ ${ }^{1}$ Department of Marine Sciences, University of South Alabama, Mobile, Alabama 36688, USA \\ ${ }^{2}$ Dauphin Island Sea Laboratory, University of South Alabama, PO Box 369, Dauphin Island, Alabama 36528, USA
}

\begin{abstract}
Chronographic tethering devices were used to investigate the effects of habitat type, prey type, tidal state and time of day on predation in the Damariscotta River, Maine $\left(43^{\circ} 57^{\prime} \mathrm{N}, 69^{\circ}\right.$ $\left.35^{\prime} \mathrm{W}\right)$ and in St. Joseph Bay, Florida $\left(30^{\circ} 00^{\prime} \mathrm{N}, 85^{\circ} 30^{\prime} \mathrm{W}\right)$. Traditional tethering data (presence/ absence) revealed that there were significant differences in the number of predation events between sites $(\mathrm{p}=0.037)$ with more predation events occurring at the St. Joseph Bay site. In addition, there were significant differences in predation between prey types $(\mathrm{p}<0.001)$. Regardless of site, significantly more 'soft' bodied prey types (shrimp) were removed than 'hard' bodied prey types (brachyuran crabs). Separating the data by site revealed that there were significant differences between habitat types (seagrass interior, seagrass edge and unvegetated substrate) at the Damariscotta River site $(p=0.027)$, but not at the St. Joseph Bay site $(p=0.943)$. Using the time to predation recorded on the chronographic tethering devices, survival times were calculated. Based on prey survival time, comparisons were made between predation intensity in monotypic stands of the seagrasses Zostera marina L. (Damariscotta River) and Thalassia testudinum (St. Joseph Bay), and bare substrate and the grass edge at both study sites. There were no significant differences in survival time between habitats at the Damariscotta River site $(p=0874)$. However, the average prey survival time was significantly less for the seagrass bed edge at the St. Joseph Bay site than for the T. testudinum bed interior and unvegetated habitats $(p=0.019)$. In addition, the time to predation allowed the effect of tidal state and light versus dark on predation to be assessed. While neither tidal state nor light versus dark had any effect on predation at the Damariscotta River site $(p=0.096$ and $p=0.481$ respectively), at the St. Joseph Bay site, there were significantly more predation events during the day than at night $(p<0.001)$, regardless of tidal state $(p=0.664)$. The use of the chronographic tethering devices revealed that while there was no significant difference in the number of predation events or rate of predation at the St. Joseph Bay site, the interface (i.e. 'edge') between bare or unvegetated substrates and seagrass assemblages was associated with the highest predation risks.
\end{abstract}

KEY WORDS: Chronographic tethering · Edge effects · Predation · Thalassia testudinum · Zostera marina

\section{INTRODUCTION}

Initial concepts concerning the factors that control marine community structure were derived primarily

\footnotetext{
${ }^{*}$ Present address: Department of Biological Sciences, Florida International University, University Park, Miami, Florida 33199, USA. E-mail: petersob@fiu.edu
}

from descriptive sampling approaches. Such research established that seagrass meadows are characterized by rich and abundant resident faunas (Kikuchi \& Peres 1977, Zieman 1982). Descriptive sampling approaches are not capable of elucidating the factors that control species richness and abundance. However, many experimental studies indicate possible controlling factors on the distribution and abundance of prey species in 
various marine habitats, including seagrass meadows (Paine 1966, Dayton 1971, Orth 1977, Peterson 1977, Reise 1977, Heck \& Thoman 1981). Numerous field and laboratory experiments have shown that seagrasses provide effective refuge for a variety of organisms (e.g. Heck \& Wilson 1987, Wilson et al. 1990, Herrnkind et al. 1997).

Tethering techniques are useful for examining the refuge potential provided by different habitat types. For example, Wilson et al. (1990) used tethering to demonstrate the importance of the macroalgae Ulva lactuca as refuge for juvenile blue crabs Callinectes sapidus, in a New Jersey salt marsh. Similarly, Rozas \& Odum (1988) showed a significant reduction in predation on mummichogs Fundulus heteroclitus inhabiting submerged aquatic vegetation (SAV) compared to those inhabiting bare substrate. Where comparisons have been made between vegetated and unvegetated habitats, most studies have found reduced predation rates for organisms living in SAV (Heck \& Thoman 1981, Minello \& Zimmerman 1983, Roza \& Odum 1988, Wilson et al. 1990, Heck \& Crowder 1991). While tethering has proven to be a useful tool in predation studies, the technique has limitations (cf. Peterson \& Black 1994, Aronson \& Heck 1995). Most often, the results of tethering studies are said to represent predation potential which is defined as the rate at which prey would be consumed if they were readily available to predators (Aronson \& Heck 1995).

Standard tethering techniques involve anchoring a prey item in different habitats by using a thin monofilament tether (Heck \& Thoman 1981). Observations are subsequently made as to whether the prey has or has not been consumed. This technique usually requires that a large number of prey be tethered. Recently, chronographic tethering devices have been utilized to obtain the time of the predation event (Minello 1993, Haywood \& Pendrey 1996). By timing when a predation event occurrs, the effects of other parameters (i.e. time of day and tidal state) on predation can be asssessed. More importantly, if time to predation is known, estimates of survival time can be derived. While several methods have been developed to determine time of predation (Somerton et al. 1988, Boggs 1992, Minello 1993, Haywood \& Pendrey 1996), the chronographic tethering technique developed by Minello (1993) and Haywood \& Pendrey (1996) is especially useful for measuring predation rates. Minello's tethering device makes use of an inexpensive clock that is modified to include a triggering device to record time. Unfortunately, the original design of Minello (1993) was not waterproof and therefore, was limited to low tidal amplitude systems in shallow water.

The purpose of this study was to use a modified Minello (1993) chronographic tethering device to answer the following questions about the varying predation pressures associated with submerged aquatic vegetation and changing environmental variables: (1) Does predation potential differ significantly between seagrass bed interiors ( $>5 \mathrm{~m}$ from the edge), edges ( $<2 \mathrm{~m}$ from unvegetated substrate) and unvegetated substrate? (2) Does predation potential differ among prey types? (3) Do time of day and tidal state affect predation potential? (4) Does prey survival time differ significantly between similar habitats across latitudes? It is important to note that the influences of site, habitat type and prey type can be estimated based upon conventional tethering data, but the effects of light, tide and prey survival time can only be determined if the time to predation is observed.

\section{MATERIALS AND METHODS}

Study sites. Field experiments were conducted in the Damariscotta River near the University of Maine's Darling Marine Center, Walpole, Maine $\left(43^{\circ} 57^{\prime} \mathrm{N}\right.$, $69^{\circ} 35^{\prime}$ W) from September 11 to September 15, 1994, and in St. Joseph Bay, Florida $\left(30^{\circ} 00^{\prime} \mathrm{N}, 85^{\circ} 30^{\prime} \mathrm{W}\right)$ in the northwest Gulf of Mexico from October 3 to October 9, 1995. The Damariscotta River site contains a soft mud substrate near shore with monotypic stands of eel grass Zostera marina. The seagrass beds used in this study were subtidal with a mean depth slightly greater than $1 \mathrm{~m}$ at low tide. Tides are semi-diurnal with a mean excursion of 3 to $4 \mathrm{~m}$. Because of the close proximity to the Atlantic ocean and little input of freshwater at the study site other than precipitation, salinity varies little, having an annual range of 26 to $34 \mathrm{psu}$. Annual temperatures range from 0 to $20^{\circ} \mathrm{C}$. St. Joseph Bay has a sandy substrate that supports dense stands of turtle grass (Thalassia testudinum). The seagrass beds used at this site were subtidal with a mean depth of approximately $1 \mathrm{~m}$ at low tide. Tides in St. Joseph Bay are diurnal with a mean excursion of $0.5 \mathrm{~m}$ (Valentine \& Heck 1993). Mean salinity is near $36 \mathrm{psu}$, but can range from 22 to $43 \mathrm{psu}$, depending on season and precipitation. Annual temperatures range from 11 to $30^{\circ} \mathrm{C}$. Comparisons of short shoot densities, aboveground biomass and leaf morphometrics for each study area are listed in Table 1.

Chronographic tethering devices. The chronographic tethering devices (CTDs) were constructed from inexpensive automobile dash mount clocks based on the design developed by Minello (1993). These clocks were chosen because they could be reset to 12:00 $\mathrm{h}$ when the battery was removed. Once reset, the clocks would not begin to keep time until a reset button was pressed. Once the reset button was pressed, the clock would continue to keep time regardless of 
how many times the reset button was subsequently pressed.

A triggering mechanism (Fig. 1) was constructed by soldering a wire tethering lead to the steel battery holder and a shorter length of wire to the circuit board where the reset button was located. Completing the circuit between these wires acted in the same way as pressing the reset button. The wire from the circuit board was wrapped around a screw on a wooden mounting board. Tether lines were attached to a loop at the end of the tethering lead by snap-on swivels. The force required to start the timer could be adjusted by rotating the clock around the mounting screw. A $1 \mathrm{~mm}$ hole was drilled in the face of the clock near the edge of the battery. By inserting a small probe into the hole, the battery/circuit board connection was severed, which reset the clock to 12:00 h.

The CTDs and triggering mechanisms were encased in $10 \mathrm{~cm}$ long $\times 5 \mathrm{~cm}$ (inside) diameter PVC tubes with caps on both ends. The original case designed by Minello (1993) used removable caps, but in preliminary tests these caps leaked when submerged. Therefore, we modified the case by sealing one end of the cylinder and gluing a threaded female adapter to the top of the canister. A threaded male cap with a sealer on the threads was then screwed into the female adapter, making the canister waterproof. This modification to the canister allowed it to act as a diving bell, trapping the air inside. The threaded cap was removed when necessary, and the CTD was removed to check for the timing of predation events. A solid cap was permanently attached to the bottom with PVC cement. A small hole was drilled through the bottom cap for the tethering lead (Fig. 1). The PVC canisters were attached to a support pole constructed of $13 \mathrm{~mm}$ galvanized electric conduit bent into an L-shape to extend the prey away from the support pole. Support poles were pushed into the sediment so that the end of the tethering lead was approximately $0.75 \mathrm{~m}$ above the sediment surface. Thus, all tethering lines were approximately the same length $(1.25 \mathrm{~m})$, regardless of location. Tethering lines were $5 \mathrm{lb}(2.27 \mathrm{~kg})$ monofilament fishing line.

Experimental design. Eighteen canisters were deployed both in Damariscotta River and in St. Joseph Bay; 6 canisters were placed in each of the 3 habitat types (seagrass interior, seagrass edge and unvegetated substrate). Once the CTDs were deployed, they remained at the same location throughout the experiment. To avoid prey entanglement, all tethering devices were placed at least $3 \mathrm{~m}$ apart. Within each habitat, CTDs were randomly assigned shrimp or crab prey. Prey type remained the same for each CTD after initial assignment throughout the experiment. To minimize the effects of prey size on predation, a narrow range of size classes was used for each prey species. Shrimp
Table 1. Biomass and plant morphology of Zostera marina at the Damariscotta River site and of Thalassia testudinum at the St. Joseph Bay site. Values represent mean and SD for measured parameters. Shoot density is presented as number $\mathrm{m}^{-2}$. Biomass values are expressed as $g$ ash-free dry weight $\mathrm{m}^{-2}$. Blade length and width are expressed in $\mathrm{cm}$

\begin{tabular}{|lcc|}
\hline & $\begin{array}{c}\text { Damariscotta River } \\
\text { (Zostera marina) }\end{array}$ & $\begin{array}{c}\text { St. Joseph Bay } \\
\text { (Thalassia testudinum) }\end{array}$ \\
\hline Edge & & \\
Shoot density & $296.00 \pm 45.80$ & $785.80 \pm 509.40$ \\
Leaf biomass & $41.30 \pm 55.80$ & $205.20 \pm 68.50$ \\
Blade length & $86.20 \pm 8.13$ & $12.40 \pm 1.43$ \\
Blade width & $0.62 \pm 0.03$ & $0.89 \pm 0.013$ \\
Interior & & \\
Shoot density & $309.00 \pm 54.30$ & $1078.20 \pm 385.10$ \\
Leaf biomass & $68.10 \pm 91.00$ & $322.50 \pm 66.30$ \\
Blade length & $104.60 \pm 5.31$ & $16.29 \pm 0.58$ \\
Blade width & $0.82 \pm 0.02$ & $1.10 \pm 0.11$ \\
& & \\
\hline
\end{tabular}

total lengths ranged from 30 to $40 \mathrm{~mm}$, while crab carapace widths ranged from 14 to $24 \mathrm{~mm}$. Sand shrimp Crangon septemspinosa and green crabs Carcinus maenus were used at the Damariscotta River site, while brown shrimp Penaeus aztecus and mud crabs Neopanope sp. were used at the St. Joseph Bay site.

Live prey items were tethered to a $1.25 \mathrm{~m}$ long monofilament lead that was looped around the carapace and held in place with a drop of SuperGlue (Ross cyanoacrylate). Each CTD was checked every $12 \mathrm{~h}$ for the presence or absence of prey, and the time when each unit was checked was recorded. When a prey item was missing, it was replaced with a new tethered prey item. Using traditional tethering data (presence/absence), an hourly predation rate was calculated. In addition, if the CTD was triggered, the time on the clock was recorded. By subtracting the time shown on the CTD from the time at which it was

Fig. 1. 'Cut-away' view of the chronographic tethering device (CTD) showing the PVC housing and all components of the timing mechanism

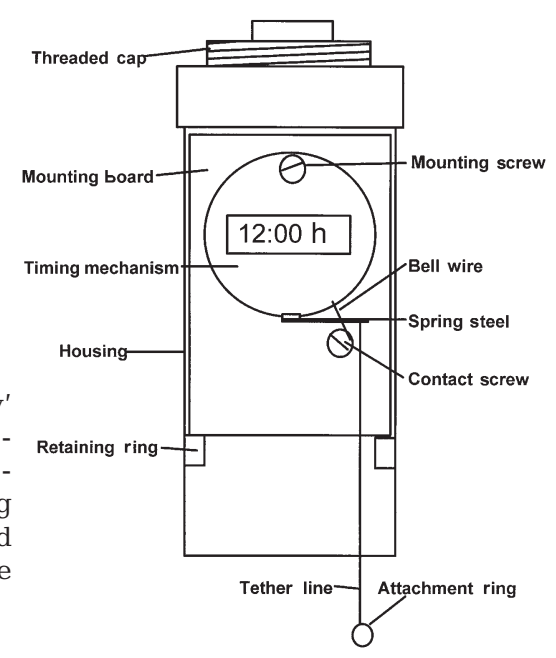


checked, it was possible to estimate the time at which the predation event occurred. Thus, both hourly predation rates and estimated prey survival times were calculated for each habitat type at both locations.

Concurrent with deployment of the CTDs, various sampling techniques were used, depending on location, to determine the suite of possible predators in each habitat. Sampling at the Damariscotta River site was conducted using an $18 \times 2 \mathrm{~m}$ seine with $6 \mathrm{~mm}$ mesh during low tide $(\mathrm{n}=30)$ and a 10 panel experimental gill net with mesh sizes ranging from 2.54 to $25.4 \mathrm{~cm}$ during high tide $(\mathrm{n}=3)$. Sampling at the St. Joseph Bay site was conducted using a $30 \times 3 \mathrm{~m}$ plankton purse seine with $1 \mathrm{~mm}$ mesh $(\mathrm{n}=45)$ and a $3.4 \mathrm{~m}$ otter trawl with $1.6 \mathrm{~cm}$ wing mesh and $0.6 \mathrm{~cm}$ cod end mesh ( $\mathrm{n}=35)$. Potential predator species were recorded based on descriptions of feeding habits in a variety of sources.

Statistical analysis. Traditional tethering data (presence/absence) were analyzed using the Pearson ChiSquare test $(3 \times 2$ contingency table $)$ and Fisher's Exact test $(2 \times 2$ contingency table) where appropriate to determine statistically significant differences between site, habitat and prey type. Three-way ANOVA $(\alpha=$ $0.05)$ was used to test for differences in predation rates across site, habitat and prey type. Data was also analyzed separately for each site using a two-way ANOVA to test for differences between habitat and prey type. When a significant effect of the response variable occurred, multiple comparison tests (Tukey's Studentized Range) were used to test for significant differences between treatments. Data for evaluating the effect of tide and light on predation were collected by using the recorded times of predation and determining the tidal state (ebbing vs flooding) and the time of day (daylight hours vs night hours). Because these data came from recorded predation events (categorical data on absent prey items), Chi-square tests could not be

Table 2. Results from the 3-way, fixed factor ANOVA on the rate of predation in both locations (St. Joseph Bay and Damarascotta River) in the 3 habitat types (Ht: seagrass bed interior, seagrass edge and unvegetated substrate) for 2 prey types (Pt: shrimp and crabs) over replicate $12 \mathrm{~h}$ periods. $\mathrm{df}=$ degrees of freedom, $\mathrm{SS}=$ sum of squares, $F=F$-ratio, and $\mathrm{p}=\mathrm{p}$-value

\begin{tabular}{|lcccc|}
\hline Source & df & SS & $F$ & $p$ \\
\hline State & 1 & 0.002 & 4.440 & 0.039 \\
$\mathrm{Ht}$ & 2 & 0.016 & 1.698 & 0.192 \\
$\mathrm{Pt}$ & 1 & 0.211 & 45.116 & 0.000 \\
State $\times \mathrm{Ht}$ & 2 & 0.018 & 1.907 & 0.157 \\
State $\times \mathrm{Pt}$ & 1 & 0.019 & 4.200 & 0.045 \\
Ht $\times \mathrm{Pt}$ & 2 & 0.002 & 0.222 & 0.801 \\
State $\times \mathrm{Ht} \times \mathrm{Pt}$ & 2 & 0.011 & 1.132 & 0.329 \\
Error & 60 & 0.280 & & \\
& & & & \\
\hline
\end{tabular}

performed (would require a $2 \times 1$ contingency table). Therefore, non-parametric Binomial tests were used to test for significant differences in prey consumed with regard to light and tidal state.

\section{RESULTS}

Although 234 experimental trials (18 CTDs $\times$ 13 twelve hour periods) were designed to be performed, 12 trials did not occur due to insufficient numbers of available prey items. This occurred primarily on Day 1 of each tethering experiment at each site. Therefore, a total of 222 experimental trials was conducted. An experimental trial was defined as the opportunity for a tethered item to be removed during a $12 \mathrm{~h}$ period. At the Damariscotta River site, there were 150 trials conducted with 39 predation events, which we defined as prey items removed from the tether $(26 \%$ predation), while at the St. Joseph Bay site, there were 72 trials and 28 predation events (39\% predation). Many of the prey items were obviously consumed because a portion of the prey item remained attached to the tether.

Using the traditional tethering data (presence/ absence), differences in predation between sites, prey types and habitat types were assessed. Since presence/absence data can be evaluated either by differences in the number of predation events or by the calculation of a predation rate, both were used. Comparing the number of predation events between sites demonstrated that overall mortality was significantly higher at the St. Joseph Bay site (Fisher's Exact test $=3.835, \mathrm{p}=0.037, \mathrm{df}=1, \mathrm{~N}=222$ ), though there were no significant differences in the number of predation events among habitat types (Pearson ChiSquare $=4.108, \mathrm{p}=0.128, \mathrm{df}=2, \mathrm{~N}=222$ ). Regardless of location (Damariscotta River or St. Joseph Bay), significantly more soft bodied prey types (shrimp) were eaten than hard bodied types (crab) (Pearson ChiSquare $=52.603, \mathrm{p}<0.001, \mathrm{df}=1, \mathrm{~N}=222$ ). At both locations, predation predominantly occurred on the soft-bodied prey items. At Damariscotta River, crab

Table 3. Results from the 2-way fixed factor ANOVA on the rate of predation at St. Joseph Bay in the 3 habitat types (Ht) for 2 prey types $(\mathrm{Pt})$ over replicate $12 \mathrm{~h}$ periods. $\mathrm{df}=$ degrees of freedom, $\mathrm{SS}=$ sum of squares, $F=F$-ratio, and $\mathrm{p}=\mathrm{p}$-value

\begin{tabular}{|lrrrr|}
\hline Source & df & SS & \multicolumn{1}{c|}{$F$} & $\mathrm{p}$ \\
\hline Ht & 2 & 0.000 & 0.046 & 0.955 \\
$\mathrm{Pt}$ & 1 & 0.135 & 24.101 & 0.000 \\
$\mathrm{Ht} \times \mathrm{Pt}$ & 2 & 0.003 & 0.327 & 0.725 \\
Error & 18 & 0.100 & & \\
\hline
\end{tabular}


Table 4. Results from the 2-way, fixed factor ANOVA on the rate of predation at Damariscotta River in the 3 habitat types (Ht) for 2 prey types $(\mathrm{Pt})$ over replicate $12 \mathrm{~h}$ periods. $\mathrm{df}=$ degrees of freedom, $\mathrm{SS}=$ sum of squares, $F=F$-ratio, and $\mathrm{p}=$ p-value

\begin{tabular}{|lrrrr|}
\hline Source & df & SS & \multicolumn{1}{c|}{$F$} & $\mathrm{p}$ \\
\hline $\mathrm{Ht}$ & 2 & 0.050 & 5.782 & 0.006 \\
$\mathrm{Pt}$ & 1 & 0.076 & 17.834 & 0.000 \\
$\mathrm{Ht} \times \mathrm{Pt}$ & 2 & 0.012 & 1.363 & 0.267 \\
Error & 42 & 0.180 & & \\
\hline
\end{tabular}

predation accounted for $12.8 \%$ of all predation events. Similarly, at St. Joseph Bay $14.3 \%$ of the predation events involved the hard-bodied prey items.

Converting the presence/absence data into predation rates (prey items removed $\mathrm{h}^{-1}$ ) revealed that, as reported above for the number of predation events, the rate of predation was significantly greater at the St. Joseph Bay site and that soft bodied prey items were removed at a significantly greater rate than the hard bodied prey items (Table 2). Again, there were no significant differences in predation rate among habitat types.

Separating the data by site and comparing habitat types revealed no significant differences in number of predation events in St. Joseph Bay (Pearson ChiSquare $=0.117, \mathrm{p}=0.943, \mathrm{df}=2, \mathrm{~N}=72$ ). Nor were there any differences in predation rate between habitats (Table 3, Fig. 2). However, at the Damariscotta River site, there was a significant difference in the number of predation events among habitat types (Pearson Chi-Square $=7.234, \mathrm{p}=0.027, \mathrm{df}=2, \mathrm{~N}=$ 150), and in predation rate between habitat types (Table 4, Fig. 2). All pairwise comparisons revealed that the unvegetated habitat had a significantly higher number of predation events than the seagrass interior and seagrass edge, which were not significantly different from each other. Similarly, Tukey's multiple comparison analysis revealed that a significantly greater rate of predation occurred over the unvegetated substrate than for the seagrass interior and seagrass edge.

During both tethering experiments (222 trials), there were 67 predation events, of which 41 were recorded on the CTDs. The additional information acquired by the CTDs was used to address the effect of tidal state, light versus dark and prey survival time per habitat type. Non-parametric Binomial tests revealed that at the Damariscotta River site, neither tide nor light had a significant effect on predation $(p=0.096$ and $p=0.481$ respectively). However, at St. Joseph Bay, although tidal state had no significant effect ( $p=0.664)$, significantly more prey were consumed during light hours $(p<0.001)$ (Fig. 3). Predation peaked in the early morn-

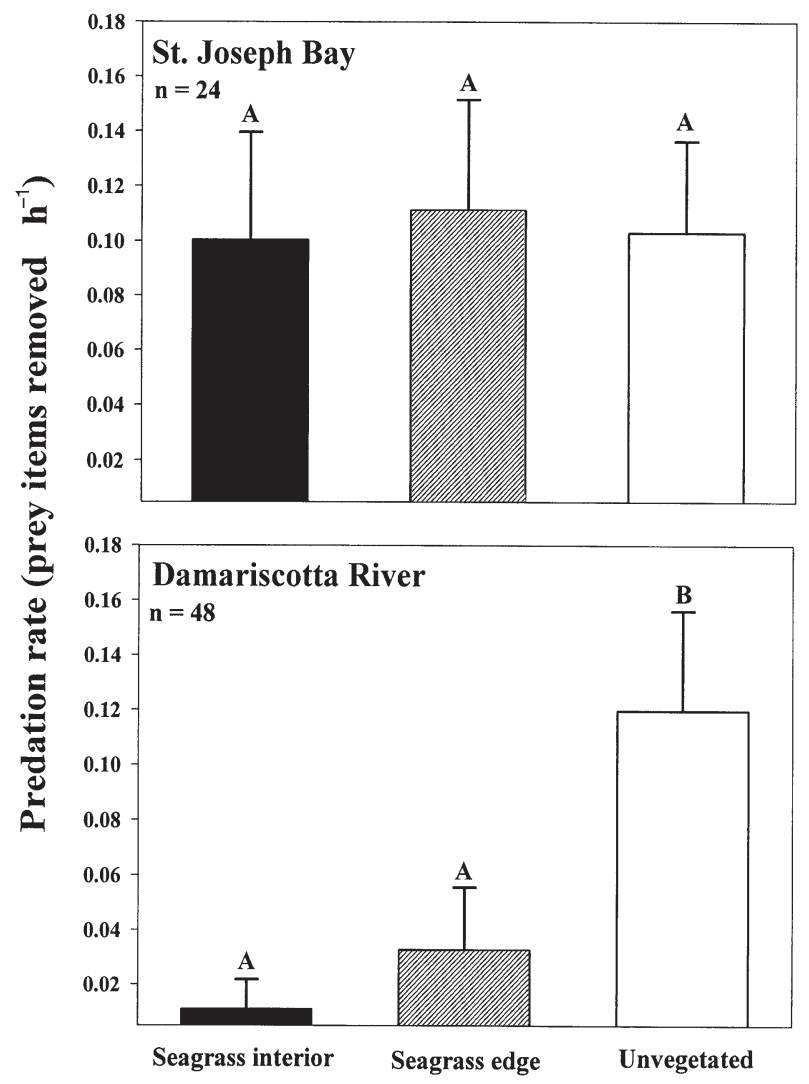

Fig. 2. Comparison of predation rates (number of prey items removed $\mathrm{h}^{-1}$ ) between the 3 habitat types for each site (Damariscotta River and St. Joseph Bay). Bars = means $\pm \mathrm{SE}$; differing letters indicate significant differences $(p<0.05)$ between habitat types using Tukey's Studentized Range multiple comparison method

ing and again in the afternoon at the Damariscotta River site, while predation at the St Joseph Bay site exhibited a single peak during the afternoon (Fig. 4).

Average prey survival times varied from approximately 0.25 to $5.25 \mathrm{~h}$, depending on location and habitat type (Fig. 5). Prey survival times were not significantly different among habitat types at the Damariscotta River site (1-way ANOVA, $\mathrm{p}=0.874, F=0.136$, $\mathrm{df}=2, \mathrm{~N}=21$ ). At the St. Joseph Bay site, prey survival time was significantly different among habitats (1-way ANOVA, $\mathrm{p}=0.019, F=4.994, \mathrm{df}=2, \mathrm{~N}=20$ ). Tukey's multiple comparison analysis revealed that survival times were significantly shorter for the edge habitat than within the grass bed or on the unvegetated habitat. Prey survival times at all Damariscotta River habitats were similar to those recorded for the unvegetated habitat in St. Joseph Bay.

The trawl, seine and net sampling data from Damariscotta River and St. Joseph Bay indicated not only a difference in the numbers of species, but also 
Tide

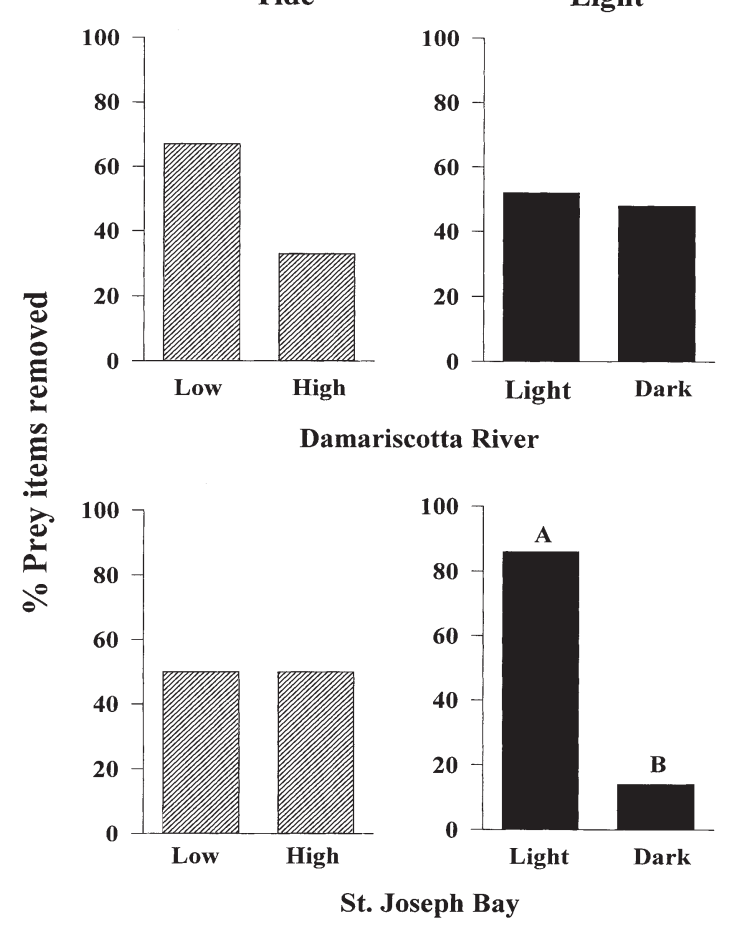

Fig. 3. Comparison of the \% of prey items removed versus tide and light for Damariscotta River and St. Joseph Bay. Differing letters indicate significant differences $(p<0.05)$ using the non-parametric Binomial test

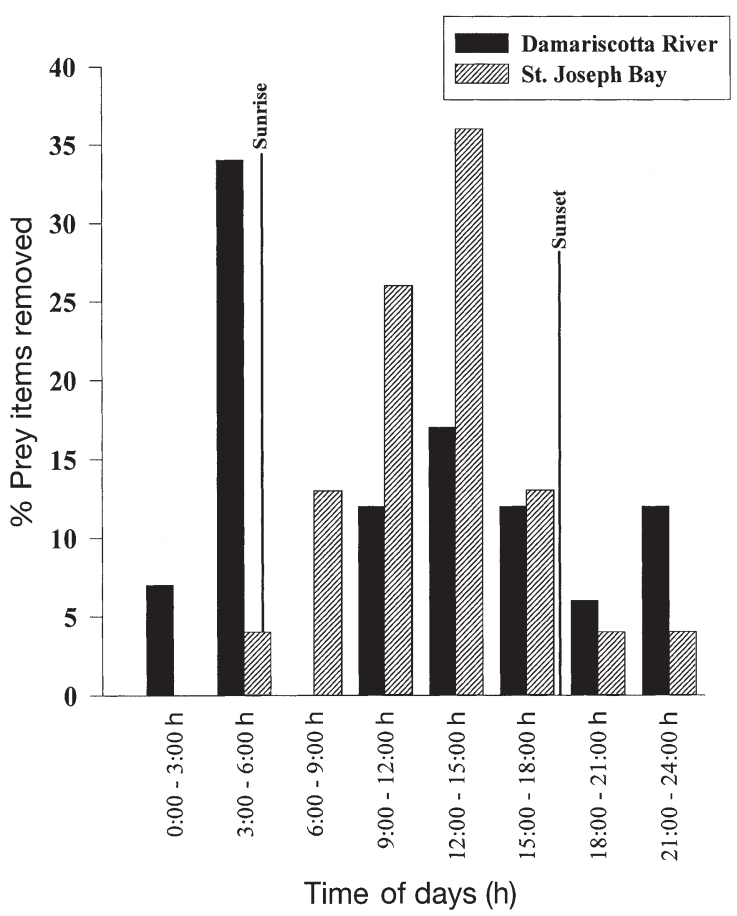

Fig. 4. Comparison of percent soft bodied prey eaten versus time of day for Damariscotta River and St. Joseph Bay differences in the density of potential predators between locations (Table 5). Predator number and densities were highest at the St. Joseph Bay site, with pinfish Lagodon rhomboides comprising $83 \%$ of the total number of potential predators at this site. Fourteen species of potential predators were recorded in St. Joseph Bay, with an estimated density of 0.62 predators $\mathrm{m}^{-3}$. Predator numbers and densities were less for the Damariscotta site, with 7 species present at densities near 0.21 predators $\mathrm{m}^{-3}$.

\section{DISCUSSION}

Predation rates have been repeatedly demonstrated to be lower in SAV than over nearby unvegetated substrates, most likely due to an increase in habitat structure and complexity provided by the seagrass canopy (Orth et al. 1984, Pollard 1984, Heck et al. 1989, Sogard \& Olla 1993). Consistent with these prior observations, the number of predation events was significantly greater and the predation rates were significantly higher in the unvegetated habitat at the Damariscotta River site. In contrast, neither the number of predation events nor the predation rates differed significantly among habitat types at the St. Joseph Bay site. Possible explanations for this difference include: (1) a reduced

Table 5. List of potential predators sampled for both sites and their total combined densities based on both the trawl and purse seine data. Note that $83 \%$ of all the predators by number were composed of pinfish Lagodon rhomboides at the St. Joseph Bay site

Damariscotta River: $\left(0.21\right.$ fish $\left.\mathrm{m}^{-3}\right)$

Winter flounder Pseudopleuronectes americanus Longhorn sculpin Myoxocephalus octodecemspinosus Shortfin sculpin Myoxocephalus scorpius Pollock Pollachius virens White hake Microgadis tomcod Striped bass Maorone saxatilis Green crab Carcinus maenus

St Joseph Bay: (0.62 fish $\mathrm{m}^{-3}$ )

Pinfish Lagodon rhomboides (83\%)

Pigfish Orthopristis chrysoptera

Silver perch Bairdiella chrysoura

Inshore lizardfish Synodus foetens

Spot Leiostomus zanthurus

Toadfish Opsanus tau

Mangrove snapper Lutjanus griseus

Speckled trout Cynoscion nebulosus

Southern flounder Paralichthys lethostigma

Black seabass Centropristis ocyurus

Gag grouper Mycteroperca microlepis

Southern stargazer Astroscopus graecum

Searobin Prionotus sp.

Blue crab Callinectes sapidus 
refuge potential for Thalassia testudinum (shorter canopy height) compared to Zostera, and/or (2) the greater number and density of potential predators has overshadowed the refuge potential of the grassbed. $Z$. marina had long ( $>1 \mathrm{~m}$ ) narrow leaves, compared to the shorter leaves of $T$. testudinum $(<0.2 \mathrm{~m}$ canopy height). An increase in habitat complexity due to leaf width variation has been shown to cause a decrease in predation in submerged aquatic vegetation (Stein \& Magnuson 1976, Middleton et al. 1984, Sogard \& Able 1991). However, shoot densities at the Damariscotta site were substantially lower than those in St. Joseph Bay.

Although SAV has been shown to reduce the risk of predation for many vertebrates and invertebrates compared to risk on unvegetated habitats (Coen et al. 1981, Stoner \& Lewis 1985, Olney \& Boehlert 1988), the relative value of refuge provided by SAV most likely decreases near the edge of the habitat due to the reduction in vegetation density (Hansson 1988). Recently, Bologna \& Heck (1999) showed that scallop mortality was significantly higher at the edge than within a seagrass bed. Our data showed no difference in predation pressure between the Zostera marina bed interior and edge, though these habitat types had significantly less predation than the unvegetated habitat. Inconsistent with the results from most previous studies, there were no differences in predation among the 3 habitat types at the St. Joseph Bay site. These observations could be influenced by differences in both habitat complexity, and available predators, but other factors may also be important.

Fish foraging behavior and prey choice are often limited by mouth structure, gape size and ability of the fish to crush or bite prey (Schmitt \& Holbrook 1984, Stoner \& Livingston 1984). Depending on the suite of predators available, differential selectivity of prey items can occur. For both the Damariscotta River site and the St. Joseph Bay site, significantly more shrimp than crabs were eaten. One possible explanation for this pattern is the preponderance of small predators (<85 mm) we collected which presumably would have difficulty handling or consuming crabs.

While shrimp were removed more frequently than crabs at both sites, overall predation was significantly higher at the St. Joseph Bay site, as demonstrated by significantly greater numbers of predation events and significantly higher predation rates. While our results agree with previous research showning an inverse relationship between predation and latitude (Bertness et al. 1981, Menge \& Lubchenco 1981, Heck \& Wilson 1987), as noted above there are many potential explanations for this pattern.

By using CTDs it was possible to determine differences in time to predation between habitats and the influence of tide and light on predation. Highest pre-

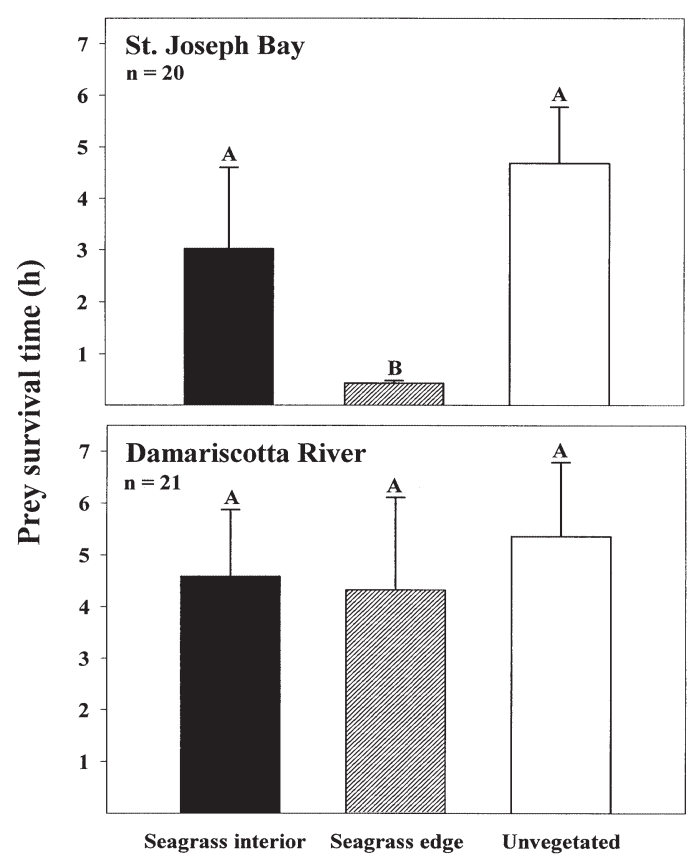

Fig. 5. Comparison of the prey survival time between habitats (grass bed, bed edge and unvegetated) in Damariscotta River and St. Joseph Bay. Bars $=$ means $\pm \mathrm{SE}_{\text {; }}$ differing letters indicate significant differences $(p<0.05)$ between habitat types using Tukey's Studentized Range multiple comparison method

dation rates were expected during high tide at the Damariscotta River site because predators were expected to move into the shallow grass beds with the rising tide. However, this was not observed. Neither tide nor light appeared to have an effect on predation at the Damariscotta River site.

Predation rates at St. Joseph Bay did not differ between high and low tide, as expected, because of the low tidal range $(\bar{x}=0.5 \mathrm{~m})$ typical of many Gulf of Mexico coastal bays. However, significantly more prey were eaten during the day than at night. One explanation for this is the specific types of predators encountered in St. Joseph Bay. Because pinfish composed such a large fraction of the predators present, their foraging may dominate the observed patterns of predation. Previous research on pinfish has shown them to be active feeders only during the day, while becoming dormant at night (Caldwell 1957).

Based on prey presence/absence data, there was no significant difference between the interior of the seagrass bed, the seagrass edge and the unvegetated substrate. However, based on average prey survival times, an edge effect appears to be present. The average prey survival time at the St. Joseph Bay site was significantly less for the seagrass edge $(\bar{x}=20 \mathrm{~min})$ than inside the Thalassia testudinum bed $(\bar{x}=120 \mathrm{~min})$. This 
pattern reflects the observations for scallop mortality found by Bologna \& Heck (1999) and suggests that in St. Joseph Bay the interface (i.e. 'edge') between bare or unvegetated substrates and seagrass assemblages is associated with the highest predation risks. While there was no significant difference in prey survival time among all 3 habitats at the Damariscotta River site, there was a trend of decreasing prey survival time from the unvegetated habitat to the interior of the Zostera marina bed to the edge.

Reduced prey survival time (i.e. time to predation) at the seagrass edge may be explained by 2 mechanisms. Seagrasses have been shown to concentrate prey. As a result of congregating prey items, predator numbers may also increase in the seagrass beds compared to unvegetated habitats. Intermediate structural complexity has been shown to be optimal for growth in predators in freshwater (Crowder \& Cooper 1981). For this relationship to be true, there needs to be a positive correlation between structure, in this case seagrass blades, and the number of potential prey available. There must also be an inverse relationship between predation rate and the structural diversity (Savino \& Stein 1982). While potential predators might find it easier to locate and catch prey over an unvegetated habitat, their own risk of predation would also increase. Conversely, while the risk of predation might decrease within a grass bed, the ability to locate and capture prey is reduced. Potential predators must balance their own risk of capture with their success in foraging (Power 1987, McIvor \& Odum 1988). It would be expected, therefore, that the rate of prey capture would increase near the edge as the structural complexity of the seagrass decreases and our results support this.

In conclusion, the additional information of time to predation, or prey survival time, gathered by CTDs revealed a functional view of the transition from unvegetated substrates to seagrass bed interior that could not be exposed with conventional tethering data. This was demonstrated by the lack of significant differences in predation rates (traditional tethering data) among habitats at St. Joseph Bay in contrast to significantly different prey survival times between habitats, which showed that the interface between vegetated and unvegetated substrates was the area of highest risk.

Acknowledgements. We thank John Valentine for preventing grievous bodily harm from occurring between B.J.P. and K.R.T. in the field. This paper was substantially improved via many discussions with and helpful comments from John Valentine and Rich Aronson. We thank the Dauphin Island Sea Lab faculty and staff for their help in all phases of this project. This is contribution no. 334 of the Marine Environmental Science Consortium and contribution no. 162 for the Southeast Environmental Research Center.

\section{LITERATURE CITED}

Aronson RB, Heck KL Jr (1995) Tethering experiments and hypothesis testing in ecology. Mar Ecol Prog Ser 12: 307-309

Bertness MS, Barrity SD, Levings SC (1981) Predation pressure and gastropod foraging: a tropical-temperate comparison. Evolution 3:995-1007

Boggs CH (1992) Depth, capture time, and hooked longevity of longline caught pelagic fish: timing bites of fish with chips. Fish Bull US 90:642-658

Bologna PAX, Heck KL Jr (1999) Differential predation and growth rates of bay scallops within a seagrass habitat. J Exp Mar Biol Ecol 239:299-314

Caldwell DK (1957) The biology and systematics of the pinfish, Lagodon rhomboides (Lannaeus). Bull Fl State Mus Biol Sci 2(6):75-173

Coen LD, Heck KL Jr, Able LG (1981) Experiments on competition and predation among shrimps of seagrass meadows. Ecology 62(6):1484-1493

Crowder LB, Cooper T (1981) Habitat structural complexity and interactions between bluegills and their prey. Ecology 63:1802-1813

Dayton PK (1971) Competition, disturbance and community organization: the provision and subsequent utilization of space in a rocky intertidal community. Ecol Monogr 41: 351-389

Hansson L (1988) Predation in heterogeneous landscapes: how to evaluate total impact? OIKOS 54:117-119

Haywood MDE, Pendrey RC (1996) A new design for a submersible chronographic tethering device to record predation in different habitat types. Mar Ecol Prog Ser 143: 307-312

Heck KL Jr, Crowder LB (1991) Habitat structure and predator-prey interactions in vegetated aquatic systems. In: Bell SS, Mc Coy ED, Mushinsky HR (eds) Habitat complexity: the physical arrangement of objects in space. Chapman and Hall, New York, p 281-299

Heck KL Jr, Thoman TA (1981) Experiments on predator-prey interactions in vegetated aquatic habitats. J Exp Mar Biol Ecol 53:125-134

Heck KL Jr, Wilson KA (1987) Predation rates on decapod crustaceans in latitudinally separated seagrass communities: a study of spatial and temporal variation using tethering techniques. J Exp Mar Biol Ecol 107:87-100

Heck KL Jr, Able KW, Fahay MP, Roman CT (1989) Fishes and decapod crustaceans of Cape Cod eelgrass meadows: Species composition and seasonal abundance patterns. Estuaries 12:59-65

Herrnkind WF, Butler MJ, Hunt JH, Childress M (1997) Role of physical refugia: implications from a mass sponge dieoff in a lobster nursery in Florida. Mar Freshw Res 48: 751-758

Kikuchi T, Perez JM (1977) Consumer ecology of seagrass beds. In: McRoy CP, Helfferich C (eds) Seagrass ecosystems: A scientific perspective. Marcel Dekker, New York, p 147-186

McGuinness KA (1997) Tests for artifacts in some methods used to study herbivory and predation in mangrove forests. Mar Ecol Prog Ser 153:37-44

McIvor CC, Odum WE (1988) Food, predation risk, and microhabitat selection in a marsh fish assemblage. Ecology 69(5):1341-1351

Menge BA, Lubchenco J (1981) Community organization in temperate and tropical rocky intertidal habitats: prey refuges in relation to consumer pressure gradients. Ecol Monogr 51:429-450 
Middleton MJ, Bell JD, Burchmore JJ, Pollard DA, Pease BC (1984) Structural differences in the fish communities of Zostera capricorni and Posidonia australis seagrass meadows in Botany Bay, New South Wales. Aquat Bot 18: 89-109

Minello TJ (1993) Chronographic tethering: a technique for measuring prey survival time and testing predation pressure in aquatic habitats. Mar Ecol Prog Ser 101: 99-104

Minello TJ, Zimmerman RJ (1983) Fish predation on juvenile brown shrimp, Penaeus aztecus (Ives): the effect of simulated Spartina structure on predation rates. J Exp Mar Biol Ecol 72:211-231

Olney JE, Boehlert GW (1988) Nearshore ichthyoplankton associated with seagrass beds in the lower Chesapeake Bay. Mar Ecol Prog Ser 45:33-43

Orth RJ (1977) The importance of sediment stability in seagrass communities. In: Coull BC (ed) Ecology of marine benthos. University of South Carolina Press, Columbus, $\mathrm{SC}, \mathrm{p} 281-300$

Orth RJ, Heck KL Jr, Van Montfrans J (1984) Faunal communities in seagraass beds: A review of the influence of plant structure and prey characteristics on predator-prey relationships. Estuaries 7:339-384

Paine RT (1966) Food web complexity and species diversity. Am Nat 100:65-75

Peterson CH (1977) Competitive organization of the soft bottom macrobenthic communities of Southern California lagoons. Mar Biol 43:343-359

Peterson CH, Black R (1994) An experimental challengewhen artifacts of intervention interact with treatments. Mar Ecol Prog Ser 111:89-97

Pollard DA (1984) A review of ecological studies on seagrassfish communities, with particular reference to recent studies in Australia. Aquat Bot 18:3-42

Power ME (1987) Predator avoidance by grazing fishes in temperate and tropical streams: Importance of stream depth and prey size. In: Kerfoot WC, Shi A (eds) Direct and indirect impacts on aquatic communities. University Press of New England, Hanover, MD, p 333-351

Reise K (1977) Predation-pressure and community structure of intertidal soft bottom fauna. In: Keegan BF, O'Ceidigh

Editorial responsibility: Otto Kinne (Editor),

Oldendorf/Luhe, Germany
P, Boaden PJS (eds) Biology of benthic organism. Pergamon Press, London, p 513-519

Rozas LP, Odum WE (1988) Occupation of submerged aquatic vegetation by fishes: testing the roles of food and refuge. Oecologia 77:101-106

Savino JF, Stein RA (1982) Predator-prey interactions between largemouth bass and bluegills as influenced by simulated, submersed vegetation. Trans Am Fish Soc 111(3):255-266

Schmitt RJ, Holbrook SJ (1984) Ontogeny of prey selection by black surfperch Embiotoca jacksoni (Pisces: Embiotocidae): The roles of fish morphology, foraging behavior, and patch selection. Mar Ecol Prog Ser 18:225-239

Sogard SM, Able KW (1991) A comparison of eelgrass, sea lettuce macroalgae, and marsh creeks as habitats for epibenthic fishes and decapods. Estuar Coast Shelf Sci 33: 501-519

Sogard SM, Olla BL (1993) Effects of light, thermoclines and predator presence on vertical-distribution and behavioral interactions of juvenile walleye pollack, TheragraChaleogramma pallas. J Exp Mar Biol Ecol 167:179-195

Somerton D, Kikkawa D, Wilson C (1988) Hook timers to measure the capture time of individual fish. Mar Fish Rev 50: $1-5$

Stein RA, Magnuson JJ (1976) Behavioral response of crayfish to a fish predator. Ecology 57:751-761

Stoner AW, Lewis FG III (1985) The influence of quantitative and qualitative aspects of habitat complexity in tropical sea-grass meadows. J Exp Mar Biol Ecol 94:19-40

Stoner AW, Livingston RJ (1984) Ontogenetic patterns in diet and feeding morphology in sympatric Sparid fishes from seagrass meadows. Copeia 1984(1):174-187

Wilson KA, Able KW, Heck KL Jr (1990) Habitat use by juvenile blue crabs: a comparison among habitats in southern New Jersey. Bull Mar Sci 46:105-114

Valentine JF, Heck KL Jr (1993) Mussels in seagrass meadows: their influence on macroinvertebrate abundance and secondary production in the northern Gulf of Mexico. Mar Ecol Prog Ser 96:63-74

Zieman JC (1982) The ecology of the seagrasses of south Florida: A community profile. US Fish Wild Serv Biol Serv Program. FWS-OBS-82/25

Submitted: September 1, 2000; Accepted: April 30, 2001

Proofs received from author(s): November 29, 2001 